\title{
Outsourcing, Occupational Restructuring, and Employee Well-being \\ Is There a Silver Lining?
}

Petri Böckerman ${ }^{*}-$ Mika Maliranta*

* Labour Institute for Economic Research, petri.bockerman@labour.fi

* ETLA - The Research Institute of the Finnish Economy, mika.maliranta@etla.fi 
This study was funded by the Finnish Work Environment Fund. This paper is also part of the project (No. 134057) financed by the Academy of Finland. Data construction and decomposition computations were conducted at Statistics Finland, following the terms and conditions of confidentiality. To obtain access to the data, please contact the Research Laboratory of the Business Structures Unit, Statistics Finland, Fl-00022, Finland. We are grateful to Antti Kauhanen for very useful comments. The usual disclaimer applies.

An identical version has been published in the Labour Institute for Economic Research discussion paper series (\#277). 
Contents

$\begin{array}{lr}\text { Abstract } & 2\end{array}$

1 Introduction 3

2 Conceptual framework 4

3 Data $\quad 8$

$\begin{array}{lll}4 & \text { Empirical specifications } & 11\end{array}$

5 Results 12

6 Conclusions 20

$\begin{array}{ll}\text { Appendix } & 22\end{array}$

$\begin{array}{ll}\text { References } & 26\end{array}$ 


\section{Abstract}

This paper explores the effects of outsourcing on employee well-being through the use of the Finnish linked employer-employee data. The direct negative effect of outsourcing is attributable to greater job destruction and worker outflow. In terms of perceived well-being, the winners in international outsourcing are those who are capable of performing interactive tasks (i.e., managers, professionals and experts), especially when offshoring involves closer connections to other developed countries.

Key words: globalization, outsourcing, offshoring, working conditions, job satisfaction, subjective wellbeing

JEL: J28, F23 
Outsourcing, Occupational Restructuring, and Employee Well-being:

Is There a Silver Lining?

\section{Introduction}

Outsourcing, especially international outsourcing (i.e., offshoring), has become the primary method that firms use to change their production structure across developed countries. Blinder (2006) claims that offshoring constitutes the next industrial revolution. Malone et al. (2011) argue that the work in developed countries will be 'atomized' into ever-smaller pieces. Offshoring has already led to the substantial vertical fragmentation of production. Linden et al. (2007) describe this process in the case of the production of Apple's iPod, and Ali-Yrkkö et al. (2011) discuss it in the context of the value chain of a Nokia smartphone. Offshoring is likely to entail occupational restructuring within firms. Consequently, offshoring increases the pace of job destruction and worker outflow, at least for those types of tasks that can be easily and profitably outsourced. Outsourcing, in general, and offshoring, in particular, can therefore be expected to have negative effects on perceived employee well-being, especially among employees who perform "offshorable" tasks. However, evidence of the effects of outsourcing on well-being among employees who are capable of keeping their jobs (i.e., stayers) is sparse, despite the importance of ongoing changes. ${ }^{11}$

This paper contributes to the literature in multiple ways. First, we use a comprehensive set of firm-level measures of offshoring, whereas much of the earlier literature has depended on industry-level proxies for offshoring. Macro data may suffer considerably from aggregation bias, which hinders the identification of the effects (Geishecker 2008). Second, using the firm-level data, we distinguish between different forms of outsourcing and examine their effects in different dimensions. We also analyze the effects of insourcing (i.e., the opposite of outsourcing). Third, through the use of the linked employer-employee data (including information on occupations and various indicators), we gauge different aspects of occupational restructuring within firms, including the destruction of tasks, characteristics (i.e., the interactive or non-routine nature) of tasks, and associated worker outflows between tasks within firms (intra-firm mobility) and between firms (inter-firm mobility). In conducting this analysis, we identify the distinct mechanisms triggered by outsourcing that are relevant for employee well-being. Fourth, using the linked employer-employee data, we merge the firm-level measures of outsourcing and intra-firm occupational restructuring with a host of employee-level indicators of well-being. In general, the literature has focused on only a few specific aspects of well-being, such as perceived uncertainty. However, different aspects of well-being are likely to produce different effects. The subsequent analysis of multiple outcomes provides a comprehensive picture of the potential effects. Fifth, the data cover the service sector. Earlier research has focused on manufacturing, but the share of manufacturing jobs has declined considerably in developed countries, and the manufacturing sector may not be a representative part of the economy. Therefore, this extension of the research allows us to determine whether the earlier findings are specific to manufacturing.

We analyze the effects of outsourcing on employee well-being in the Finnish context. The pressures of globalization are particularly pronounced in Finland because it is a small, open economy with a high level of wages and benefits. In recent years, considerable changes have occurred in Finland's trade patterns. For example, the share of non-OECD countries in the total Finnish manufacturing trade increased by roughly ten percentage points during 1999-

See Crinò (2009) and Eriksson (2010) for surveys of the labor market effects of multinational firms, internationalization, and offshoring. For example, Østhus and Mastekaasa (2010) study the impact of downsizing on sickness absence. 
2004. Within the manufacturing sector, the electronics industry has rapidly increased its outsourcing in the past ten years. Furthermore, the Finnish labor market has been in a state of continuous turbulence for decades (Ilmakunnas and Maliranta 2011). On average, more than ten percent of all jobs in the Finnish business sector are eliminated annually, and this trend has been stable in recent years. Worker inflow and outflow rates have been more than twofold. Despite increasing globalization and turbulent labor markets, however, according to the Eurobarometer, ${ }^{2}$ life satisfaction in Finland has been at a high level with a stable or increasing trend (see Lehto and Sutela 2009). This is not to say, of course, that globalization, with its various forms and associated labor market effects, has been irrelevant for well-being, especially for those who are most vulnerable to its impacts. However, offshoring may play an important role in reshaping occupational structures in a manner that not only increases the labor productivity and competitiveness of the economy but may also provide more satisfying job characteristics (e.g., more interactive and less routine tasks) for employees who are able to keep their jobs in the process of restructuring.

The negative effects of offshoring on employee well-being have gained considerable attention in the literature and, especially, in public debate. However, broader considerations suggest that offshoring is likely to have a positive effect for at least two reasons. First, offshoring is part of the restructuring process that involves an increase in the share of high value-added occupations in the economy. We document direct evidence for this because offshoring increases the share of knowledge workers in the affected firms. Restructuring also fuels the economic growth that is found to increase happiness in developed countries (Sacks et al. 2010; Stevenson and Wolfers 2008). Second, our results point out that the offshoring-triggered restructuring mechanism increases the share of occupations in the affected firms that are not only well paid but are also fulfilling because the perceived well-being derived from them is high in several dimensions.

This paper proceeds as follows. We first describe the conceptual framework and the linked data. An overview of the empirical specifications is provided next. The estimation results are then presented and a summary concludes.

\section{Conceptual framework}

Dimensions of Outsourcing and Its Links to Employee Well-being. Figure 1 illustrates the conceptual framework of the analysis. The ultimate aim is to understand how outsourcing at the firm level affects the well-being of staying employees. We pay particular attention to the role of occupational reorganization within firms as a conveying mechanism between outsourcing and employee well-being. Furthermore, we emphasize the fact that each of the three parts of the analysis - outsourcing, occupational restructuring and well-being - has diverse dimensions that warrant close scrutiny. Figure 1 reveals how the combined data (described in detail in the next section) provide an exceptional opportunity to examine the three closely interlinked parts and their multiple dimensions. Rich data sets on outsourcing and employee wellbeing and careful measurement of the different aspects of occupational restructuring, using a comprehensive set of indicators, enable us to disentangle the mechanisms of outsourcing and perceived well-being. This allows us to examine whether the negative effects of outsourcing

See http://ec.europa.eu/public_opinion/index_en.htm. 
Outsourcing, Occupational Restructuring, and Employee Well-being:

Is There a Silver Lining?

(for employees who are made redundant) might be accompanied by positive, counterbalancing impacts.

The negative effects of outsourcing on employee well-being are evident. By definition, outsourcing means that certain tasks are eliminated (i.e., moved to other local firms or abroad); thus, the demand for this type of labor in the firm decreases. Arguably, a substantial proportion of the negative impact on well-being originates from the expected losses of firm-specific human capital, quasi-rents (a worker expects to earn less in the future) and costs incurred by the search for a new job. It should also be noted that the workers who manage to keep their jobs might experience a decrease in perceived well-being. First, the decision to outsource might indicate further actions of a similar sort; thus, the recent outsourcing may increase uncertainty about the future. Second, a reduction in personnel may entail decreased prospects for promotion, a weakened bargaining position and voice in the organization, and an increased sense of discrimination because only some employees are subject to outsourcing. Third, outsourcing is associated with downsizing in some tasks, with the result that work intensity might be higher. All of these circumstances suggest that the expected effect on satisfaction level is negative.

Figure 1 Dimensions and links between outsourcing and employee well-being

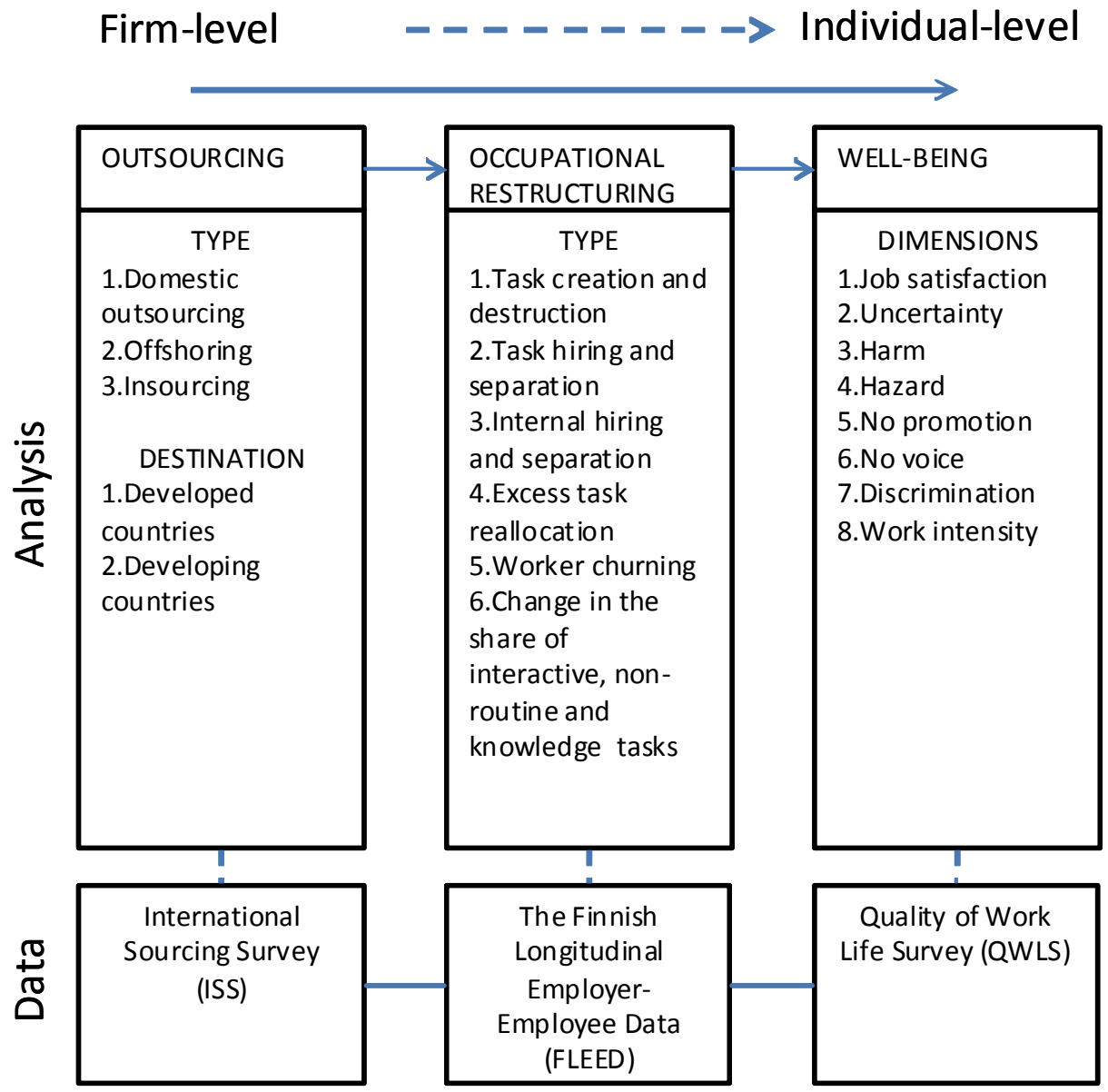


The link between outsourcing and well-being is more ambiguous when the variability in outsourcing, the heterogeneity of employees, and the different aspects of well-being are fully considered. In other words, outsourcing is likely to have diverse effects on different dimensions of well-being. The effects may also vary significantly between different types of surviving employees because the adjustment does not treat all employees equally. Some employees may gain in the process, while others may lose. This potentially obscures the general relationship between outsourcing and perceived well-being. For instance, knowledge workers may benefit disproportionately from offshoring because it creates opportunities for them to utilize their skills.

The effects may also differ by the geographical destination of outsourcing. Surviving employees may perceive offshoring to developing countries as a sign of weakness in the firm's position in the market. Moreover, the quality of jobs is drastically lower in developing countries than in Finland, which constitutes a potential threat to domestic labor standards. Indeed, there is some previous support for the heterogeneity of the effects of offshoring. Geishecker et al. (2011) reported that outsourcing to high-wage countries significantly improves the perceived level of job security among German employees, but offshoring to developing countries has the opposite effect. Furthermore, the underlying motivation for offshoring may have implications for its subsequent well-being effects. In particular, it is reasonable to argue that offshoring should have more negative effects on employee well-being if the activity is motivated by the reduction of labor costs rather than by opening new markets for products and services that would benefit both the firm and its workforce in the long run. ${ }^{3}$ The bottom line of the discussion about the potential heterogeneity of the effects is that there is an apparent need to estimate specifications that allow for flexible effects.

Measurement of Occupational Restructuring. A firm is a collection of jobs with different tasks. Occupational restructuring is the result of task creation and destruction in the firm. We gauge various aspects of intra-firm occupational restructuring by applying the standard measures of job and worker flows at the level of firms instead of at the level of a sector or an industry, as is typically done in the literature (Burgess et al. 2000; Davis and Haltiwanger 1999). To measure task creation and destruction, we identify the number of workers in different tasks in the firm using the ISCO-88 classification of occupations at the 1-digit level. ${ }^{4}$ The groups are as follows:

1. Managers

2. Professionals

3. Technicians and associate professionals

4. Clerks

5. Service and care workers and shop and market sales workers

6. Craft and related trade workers

7. Plant and machine operators and assemblers

8. Elementary occupations.

\footnotetext{
Ali-Yrkkö (2007) has reported that cost savings have been an important motivation behind outsourcing for the Finnish companies. $4 \quad$ Skilled agricultural and fishery workers are excluded from the analysis because we focus solely on the non-farm business sector. Our general approach resembles the approaches of Bauer and Bender (2004) and Askenazy and Moreno Galbis (2007), who also study intra-firm organizational changes.
} 
Outsourcing, Occupational Restructuring, and Employee Well-being: Is There a Silver Lining?

Task creation (TC) in firm $i$ is the sum of positive employment changes in the tasks $(j=1, \ldots, 8)$ between year $t$ and $t-1, T C_{i t}=\sum_{j=1}^{j=8} \Delta L_{i j t}^{+}$, where $\Delta$ denotes the difference operator and the superscript "+" indicates that $L_{i j t}>L_{i j, t-1}$. Task destruction (TD) is defined analogously: $T D_{i t}=\sum_{j=1}^{j=8}\left|\Delta L_{i j t}^{-}\right|$, where the superscript “-” indicates that $L_{i j t}<L_{i j, t-1}$. The net employment change in firm $i$ is $N E T_{i t}=\sum_{j=1}^{j=8} L_{i j t}-\sum_{j=1}^{j=8} L_{i j, t-1}$. Therefore, a firm may experience simultaneous task creation and destruction. Following the literature on job flows, a suitable indicator of such actions is excess task reallocation $(E T R): E T R_{i t}=T C_{i t}+T D_{i t}-N E T_{i t}$

The measures of worker flows provide a useful extension to the analysis of occupational restructuring. It holds that $N E T_{i t}=T C_{i t}-T D_{i t}=H_{i t}-S_{i t}$, where $H$ (hired) denotes the number of employees who were hired for the current task in year $t$, and $S$ (separated) indicates the number of employees who left their task in year $t$. The hired employees consist of two groups: internally hired $(I H)$ employees, who worked for the same firm (but in a different task) in year $t-1$, and externally hired $(E H)$ employees, who did not work for the same firm in year $t-1$. Analogously, the separations can be divided into internally separated (IS) and externally separated (ES). Thus, it holds that $N E T_{i t}=T C_{i t}-T D_{i t}=H_{i t}-S_{i t}=I H_{i t}+E H_{i t}-I S_{i t}-E S_{i t}$. By definition, $I H_{i t}=I S_{i t}$. To measure the amount of "excessive" worker turnover in the firm, we can use the churning flow measure: $C F_{i t}=H_{i t}+S_{i t}-\left(T C_{i t}+T D_{i t}\right)$.

Following the convention in the literature on job and worker flows, all flow measures are converted into rates by dividing them by the average employment of the firm in year $t$ and $t-1(A L) ; A L_{i t}=\left(\sum_{j=1}^{j=8} L_{i j t}+\sum_{j=1}^{j=8} L_{i j, t-1} / 2\right)=\left(L_{i t}+L_{i, t-1}\right) / 2 .{ }^{5}$ In the empirical analysis, we do not use annual changes (i.e., changes between $t$ - 1 and $t$ ); instead, we use a six-year window (i.e., changes between 2000 and 2006). This choice is dictated by the structure and content of our data. Furthermore, longer differences are useful for capturing time-consuming and gradual mechanisms, such as those examined in this study, especially when the data contain some short-run "noise" (Griliches and Hausman 1986).

In addition to the measures of task flow rates, we also apply indicators that gauge the share of interactive and non-routine tasks in the firms. By measuring the changes in these indicators between 2000 and 2006, we can explore interesting characteristics of occupational restructuring at a more detailed level. This opportunity exists because the indicators of the shares of interactive and non-routine tasks are defined by using the ISCO- 88 classification of the occupations at the 2-digit level, following Becker et al. (2009). ${ }^{6}$ Non-routine tasks involve non-repetitive work methods and creative problem solving; they cannot be programmed as simple rules. Interactive tasks require personal interaction with co-workers or third parties. This categorization of different occupations in terms of their content is related to the measures of outsourcing because routine and non-interactive tasks are most easily offshored (Baldwin 2006; Becker et al. 2009). A more straightforward measure of occupational restructuring consists of the change in the share of knowledge workers between two points in time. In the empirical analysis, "knowledge workers" comprise a broad category, including the first four occupational

A useful property of using the average employment as a denominator is that the growth rates are symmetric around the zero (Davis and Haltiwanger 1999).

6 Nilsson Hakkala et al. (2009) use the same classification of occupations and the same information on the skill content of tasks. 
groups (i.e., managers, professionals, technicians and associate professionals, and clerks) because, in most workplaces, technicians and associate professionals as well as clerks work in close co-operation with professionals. ${ }^{7}$

Therefore, in the empirical specifications, we use the following eleven measures of occupational restructuring: 1) task destruction rate, 2) task separation rate, 3) external task separation rate, 4) internal task separation rate, which is equal to the internal task hiring rate, 5) excess task reallocation rate, 6) churning flow rate, 7) the change in the share of interactive tasks, 8) the change in the share of non-routine tasks, 9) task creation rate, 10) task hiring rate, and 11) the change in the share of knowledge workers.

\section{$3 \quad$ Data}

The analysis is based on rich, linked data that combine three different data sources (see the bottom panels of Figure 1). Each source has substantial merits for the study of the effects of outsourcing.

International Sourcing Survey. To measure firms' outsourcing activities, we use a firm-level survey, the International Sourcing Survey (ISS) of Statistics Finland (SF), conducted in 2009 (see Statistics Denmark et al. 2008). The questions on this survey refer to domestic outsourcing and offshoring during the period 2001-2006 and cover the non-financial business sector (NACE, sections C to I and K). The focus of the ISS was on large enterprises because multinational enterprises are considered key players, particularly in offshoring. A random sample of smaller firms (50-99 employees) was also analyzed, but the coverage of the survey on larger firms (at least 100 employees) is much more complete. The response rate of the survey was $80 \%$. The final data cover 1,400 firms. Approximately 300 of these firms have a workforce of 50-99 employees, and other firms in the survey have at least 100 employees. Because of the framework of the questionnaire, the data cover a substantial proportion of the total employment in the Finnish business sector. For example, in the manufacturing sector, the ISS coverage is $60 \%$. In the service sector, the coverage is $46 \%$ of the firms that employ at least 5 persons (Maliranta 2011).

Offshoring is defined in the ISS as the total or partial movement of business functions (core or support business functions) currently performed in-house or domestically outsourced by the resident enterprise to either non-affiliated (external suppliers) or affiliated enterprises located abroad (Statistics Denmark et al. 2008, p. 13). All outsourcing indicators used in the following analysis measure the outsourcing of a firm's core business functions because the outsourcing of these functions is likely to have an effect on surviving employees' well-being. ${ }^{8}$ The ISS also includes information about domestic outsourcing, the geographical destinations of offshoring, the firms' motivations for offshoring and information on insourcing (i.e., the opposite of offshoring) of core business functions.

\footnotetext{
Hopp et al. (2009) consider specific aspects of white-collar tasks at the individual, team and organization levels.

8 The definition of core business function is the production of final goods or services intended for the market or for third parties that are conducted by the enterprise and yield income. In most cases, the core business function equals the primary activity of the enterprise. It may also include other (secondary) activities if the enterprise considers these to be part of its core functions (Statistics Denmark et al. 2008, p. 13).
} 
Outsourcing, Occupational Restructuring, and Employee Well-being:

Is There a Silver Lining?

Finnish Linked Employer-Employee Data. The second configuration of data that we use in the analysis is the Finnish Longitudinal Employer-Employee Data (FLEED). These data are constructed from a number of different registers on individuals and firms that are maintained by SF. They contain information from Employment Statistics, which records each employee's employer during the last week of each year. FLEED are primarily used to measure occupational restructuring in firms using the measures of task flows proposed by Maliranta $(2009,2011)$. The measures of occupational restructuring are based on the ISCO-88 classification at the 1-digit level (Maliranta 2009, 2011), as described earlier. ${ }^{9}$ One important advantage of these measures is that, by design, they are able to take into account the intensity of restructuring. In contrast, the measures of outsourcing from the ISS are binary indicators.

Quality of Work Life Survey. The third set of data that we use is the latest edition (2008) of the Quality of Work Life Survey (QWLS) of SF to measure employee well-being (Lehto and Sutela 2009). The QWLS provides a representative sample of Finnish wage and salary earners (the self-employed are excluded). The initial sample for this survey is derived from a monthly labor force survey (LFS) by SF, for which a random sample of the working-age population is selected for telephone interviews. The representative sample of employees in the QWLS provides a significant advantage over previous studies, which have focused on a few manufacturing industries or single firms. The estimates for certain sectors and firms could be subject to selection bias if the unobserved factors that determine whether employees choose to work in the sector or firm also influence their perceived well-being.

The 2008 QWLS was based on the LFS respondents in March and April who were 15-64 years old and had a normal weekly working time of at least ten hours. 6,499 individuals were selected for the QWLS sample and invited to participate in a personal face-to-face interview. Of this sample, 4,392 persons participated (approximately 68\%) (Lehto and Sutela 2009), which was a very high response rate $(68 \%)$ for a complex and burdensome face-to-face survey. The average length of the interviews was 66 minutes. Face-to-face interviews ensure reliable answers to almost all questions. Due to missing information on some variables for some employees, the final sample size of the QWLS included approximately 4,300 observations ( $~ 30 \%$ of these cover the public sector, which is not included in our analysis). The QWLS is supplemented with information from the LFS and several registers maintained by SF. For example, information about the educational level of employees originates from the Register of Completed Education and Degrees.

We used several variables to capture employee well-being, based on the QWLS. Some of these measures were general measures of well-being at work, such as job satisfaction, while other variables captured more specific aspects of employee well-being, such as perceived work intensity. Job satisfaction was measured on a four-point Likert scale. Negative job aspects were measured according to Böckerman and Ilmakunnas (2008). For perceived uncertainty, the respondents stated whether certain aspects were insecurity factors, including the threat of temporary dismissal and the threat of unemployment. Perceived harms were rated on a fivepoint scale, with the highest category corresponding to an employee's perception that a certain working condition was 'very much' an adverse factor in the workplace. Harms included heat, cold, and dust, among others. For perceived hazards, the most serious of three possibilities was

\footnotetext{
9 Maliranta (2011) provides detailed descriptive evidence on the roles of occupational restructuring in the context of the Finnish business sector.
} 
the respondent's designation of a particular workplace feature as 'a distinct hazard'. Hazards included accident risk, strain injury risk, and work exhaustion risk, among others. Responses to the questions about adverse working conditions were aggregated by creating a dummy variable equal to one if there was at least one clearly adverse factor (Harm), a dummy variable equal to one if there was at least one distinct hazard (Hazard), and a dummy variable for at least one insecurity factor (Uncertainty). $10^{10}$ These formulations were not particularly sensitive to potential measurement error in the self-reported measures of working conditions. Furthermore, we used indicators for poor promotion prospects, lacking a voice in the workplace, and experiencing at least one type of discrimination. Finally, we captured perceived work intensity by using the respondent's agreement with the statement, 'Work pressure increases sickness absence'.

Matching. Matching these three data sources is possible because all of the data sets that we use contain the same unique identifiers for firms and persons, maintained by SF. This information also ensures near-perfect traceability of employers and employees over time. The QWLS and FLEED are matched by using the unique ID codes for persons. Using FLEED, we can follow the employees who participated in the 2008 QWLS over the period 1990-2007. In each year, we can link information on the firm and the establishment to each person. The combination of the QWLS and FLEED can then be matched to the ISS by using the unique firm codes. The variables that are used in the empirical specifications are described in detail in the Appendix (Table A1).

The QWLS is a cross-sectional data set that includes only limited self-reported information on past labor market experience. However, because FLEED can be used to incorporate information on employees' work history over the period 1990-2007, we are able measure various labor market outcomes in the past. This is particularly important in our context because we are unable to estimate specifications with individual fixed effects. By using the variables that describe past labor market outcomes, we are able to take into account otherwise unobservable determinants of subjective well-being (see Lechner and Wunsch 2011, for an application of this idea in another context). The specifications that we estimate for employee well-being assume that unobserved heterogeneity is not correlated with the explanatory variable of interest to establish a causal effect. In the empirical specifications, we use past average earnings and the number of employment and unemployment months to describe employees' relevant work history.

Because the QWLS data are from 2008, in the final estimation sample, we use only those employees who were employed in the same firm during the period 2006-2008. The matched data contain 770 observations. This number reflects the fact that the ISS data are much more likely to pertain to large firms. The final estimation sample contains observations on 367 firms; therefore, we have, on average, two observations for each firm. We also estimate separate specifications for knowledge workers, with a sample size of 421 . The specifications that use the measures of occupational restructuring are based on a larger data set of 1,174 observations because we do not have to rely on a firm-level survey (ISS). Instead, we can use comprehensive register data from FLEED to construct the measures of turbulence. The number of different firms in this sample is 796 .

\footnotetext{
10 The most common elements of uncertainty are 'unforeseen changes', 'work load increases beyond tolerance', and 'transfer to other duties. These components of uncertainty typically affect the same employees. The perception of the threat of becoming incapable of work is also quite common ( $25 \%$ of all employees). This threat is much more frequent among older employees, as expected. Note that we control for the age effects in all specifications for perceived well-being.
} 


\section{$4 \quad$ Empirical specifications}

The initial step in the analysis is to establish the impact of outsourcing on occupational restructuring by using firm-level regressions (the first and second panels of Figure 1). These estimates reveal the direct effects of outsourcing on employees. The specifications take the following form:

$\operatorname{RESTRUCTURING}_{j k}=\beta \boldsymbol{X}_{j}+\operatorname{SOUTSOURCING}_{j}+\varepsilon_{j}, \quad k=1, \ldots, 11$,

where RESTRUCTURING $G_{j k}$ represents the measure $k$ of occupational restructuring for firm $j$. We use as the dependent variables eleven different measures of occupational restructuring, as described earlier. $\boldsymbol{X}_{j}$ represents the vector of control variables, which include the size of the firm (the logarithm of employment) and the industry effects (with a set of indicators for 22 industries). The variable of interest is the measure of outsourcing. In all specifications, the baseline category is that the firm has neither outsourced domestically nor offshored its core business functions during the period 2001-2006. These specifications are estimated by using employment-weighed OLS. With this approach, the firm-level regressions of equation (1) can be interpreted as data with observed means on individual employees. Descriptive statistics (Table A2, Columns 1-3) reveal that the data contain information on firms that collectively employ 350,000 employees, which is approximately one-fourth of all Finnish private sector employees. Approximately 100,000 employees have worked in firms that have been subject to some type of outsourcing.

To examine the connection between outsourcing and perceived well-being among surviving employees (the first and third panels of Figure 1), we estimate specifications with the following structure:

$Y_{i j k}=\beta \boldsymbol{X}_{i j}+\eta$ OUTSOURCING $G_{j}+\varepsilon_{i j}, \quad k=1, \ldots, 8$,

where $Y_{i j k}$ is the measure $k$ of employee well-being for individual $i$ employed in firm $j$. We use as the dependent variables eight different measures of employee well-being. $\boldsymbol{X}_{i j}$ represents the control variables, which incorporate the standard individual-level covariates, such as employees' age and education level, based on the literature on subjective well-being (Clark 1996). The standard errors in all specifications of equation (2) are clustered at the firm level. Columns 4-5 of Table A2 provide descriptive statistics for the employee-level data.

Note that outsourcing activities can be treated as exogenous to individual employees. The evidence indicates that offshoring firms are more productive than non-offshoring firms (Wagner 2011). For various reasons, we expect a positive relationship between productivity and wages at the firm level, and the empirical evidence supports this expectation (Abowd et al. 1999; Bagger et al. 2010). Equation (2) can be interpreted as a test of the existence of compensating wage differentials because outsourcing can be seen as a potential disamenity from the employees' point of view. It can be shown that the wage and its determinants should not be included among the right-hand side variables of the equation if the objective is to test for the existence of compensating wage differentials by using information on subjective well-being (see Böckerman et al. 2011). In principle, the presence of some sort of bias in our estimates cannot be fully ruled out because, for instance, some employees may be able to anticipate upcoming out- 
sourcing. However, given our context, this bias is likely to be negligible, and the direction is uncertain.

Finally, we explore the effect of occupational restructuring on surviving employees' well-being (the second and third panels of Figure 1). For this purpose, we use specifications with the following structure:

$Y_{i j k}=\beta \boldsymbol{X}_{i j}+\lambda R E S T R U C T U R I N G_{j l}+\varepsilon_{i j}, \quad k=1, \ldots 8 \quad l=1, \ldots 11$,

where $Y_{i j k}$ is the measure $k$ of employee well-being for individual $i$ employed in firm $j$. The explanatory variables of interest are each separate measure $(l=1, \ldots, 11)$ of occupational restructuring. The vector of control variables $\boldsymbol{X}_{i j}$ is exactly the same as in equation (2). The last two columns of Table A2 document descriptive statistics for the data that are used with these specifications.

\section{$5 \quad$ Results}

Outsourcing and Occupational Restructuring. We first examine whether the outsourcing activities of Finnish firms are associated with occupational restructuring and, if so, in what ways. Because we are particularly interested in the role of firms' outsourcing from the perspective of employees, the baseline estimates refer to employment-weighted regressions (Table 1). ${ }^{11}$ An additional advantage of the employment-weighted regressions is that they put greater emphasis on larger firms, for which the measures of occupational restructuring are more reliable (Ilmakunnas and Maliranta 2005). The results in Table 1 refer to continuing firms because most of the restructuring occurs among them. With this restriction, we avoid the asymmetries caused by entries and exits. Because we include the full set of industry indicators among the control variables, the results point to within-industry effects.

The estimates of equation (1) reported in Table 1 reveal a coherent pattern. Statistically, offshoring has a very significant positive relationship with the rates of task destruction and task separation (Panel A, Columns 1-2). The latter connection prevails because of external task separation (Panel A, Column 3). In contrast, offshoring is not connected to internal task separation (and, thus, neither is internal task hiring; see Panel A, Column 4). Furthermore, the effect of offshoring on the "creative" side of occupational restructuring appears to be negative, as indicated by the significant negative coefficients for the task creation and task hiring rates (Panel A, Columns 9-10). The point estimates of offshoring on the shares of interactive and non-routine tasks (at the 2-digit level of the ISCO-88 classification) are positive, but the effects are not statistically significant (Panel A, Columns 7-8). Our broader measure of the composition of the workforce gives support to the argument that offshoring contributes significantly to the increase in knowledge work in firms (Panel A, Column 11).

Panel B of Table 1 provides a more detailed breakdown of outsourcing according to geographical destination. We find that offshoring for the rest of Europe and developing countries has the most pronounced positive effects on task destruction and task separation (Panel B, Columns 1-2). These types of offshoring have a positive impact on the share of knowledge work

We use the average employment in 2000 and 2006. 


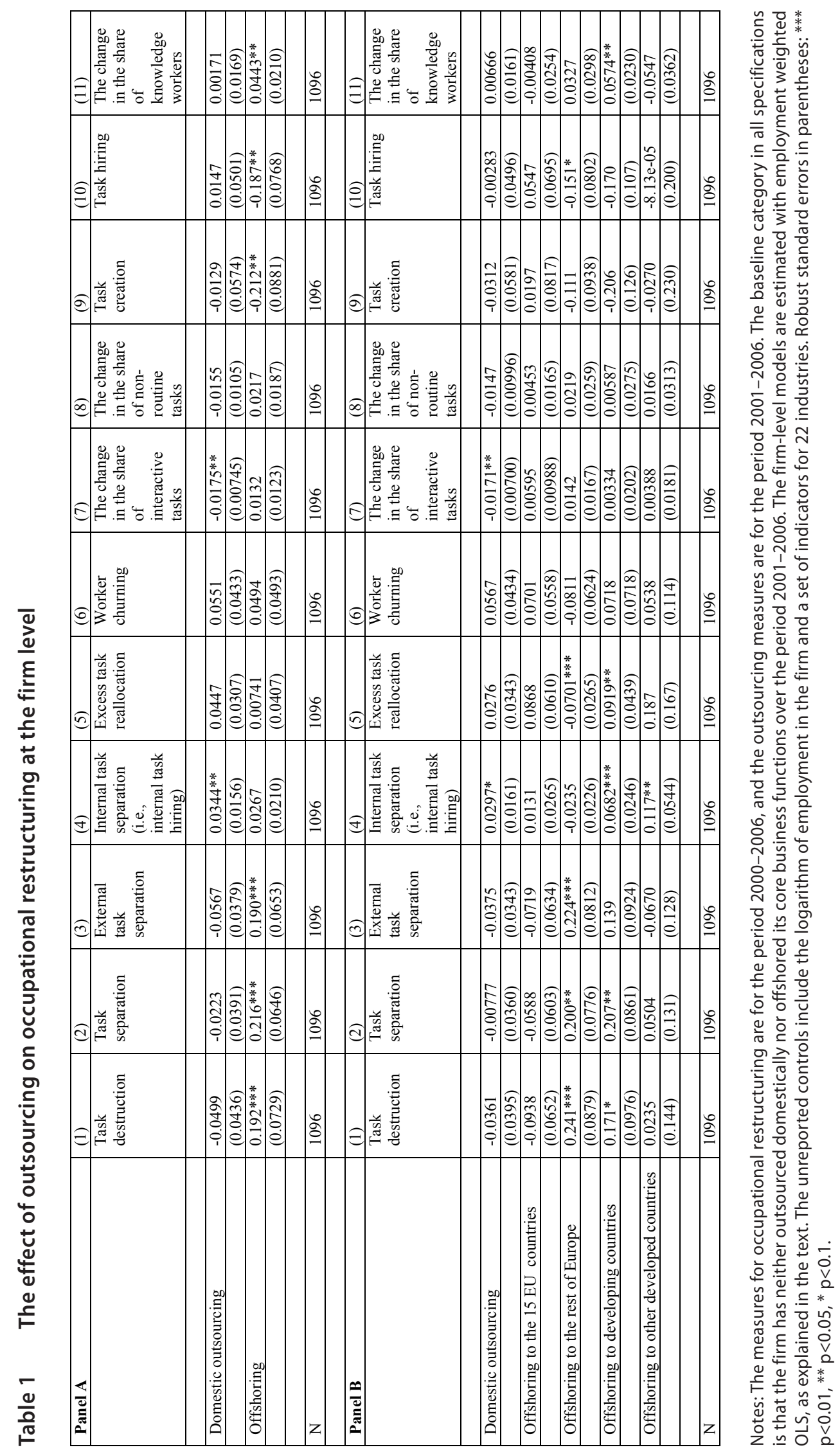


(Panel B, Columns 11). This result implies that the adverse effects are, as expected, concentrated on blue-collar tasks. It is particularly interesting to observe that offshoring to other developed countries does not have significant effects on task creation or destruction or on the change in the structure of tasks. However, it does have a strong positive effect on internal mobility (measured by internal task separation), which likely reflects the ongoing changes in organizational structure (Panel B, Column 4).

The effects of domestic outsourcing are notably different from offshoring. Interestingly, this outsourcing has a negative effect on the share of interactive tasks in the firms (Panels A-B, Column 7). The effect on the share of non-routine tasks is also negative, but statistically insignificant. Domestic outsourcing is positively associated with internal separation (and thus internal hiring), indicating that it promotes intra-firm occupational mobility (Panels A-B, Column 4).

Overall, the evidence clearly indicates that outsourcing has an important effect on occupational restructuring and that it can be expected to have direct adverse effects on the well-being of employees due to its effect of increasing task destruction and task separation in firms. However, the results also reveal that part of occupational restructuring takes place through internal task separation (and thus internal task hiring). This type of mobility is not necessarily solely negative from the point of view of the employees involved.

Outsourcing and the Well-being of Employees. Next, we examine how firms' outsourcing affects different dimensions of well-being among surviving employees, based on equation 2 (Table 2). ${ }^{12}$ Note that the descriptive statistics for the outsourcing variables confirm that the employee-level data remain representative compared to the employment-weighted firm-level data (Table A2, Columns 3 and 5). Before examining the effects of outsourcing, we first note that the occupation group has a significant impact on employee well-being. Table 2 shows that perceived well-being is particularly low among service and sales workers as well as among the typical blue-collar occupations. The latter group of occupations also has particularly poor (physical) working conditions (Panel A, Columns 3-6).

An important finding is that offshoring does not have an independent, statistically significant effect on any measure of employee well-being, conditional on occupational group and individual-level control variables (Panel A). There is, however, some evidence that domestic outsourcing has a positive impact on job satisfaction that can be attributed to a lower level of harm (Panel A, Columns 1 and 3). The estimates for the (unreported) control variables that are included in all specifications of Table 2 are in accordance with previous studies that have used various Finnish data sets to estimate well-being equations. ${ }^{13}$

It is notable that the estimates in Panel A of Table 2 do not reveal a significant impact of outsourcing on perceived uncertainty in the Finnish context. Previous evidence has related offshoring and other measures of globalization to job-loss fears (e.g., Scheve and Slaughter 2004; Geishecker et al. 2011; Lurweg 2010). There is also some evidence for these effects from other Nordic countries. Munch (2011) reports that outsourcing somewhat increases the unemployment risk of low-skilled workers in the Danish manufacturing sector. These findings are rel-

\footnotetext{
2 The correlations between the variables that capture working conditions are reported in Table A3.

13 The estimation results for the control variables are available upon request.
} 
Is There a Silver Lining?

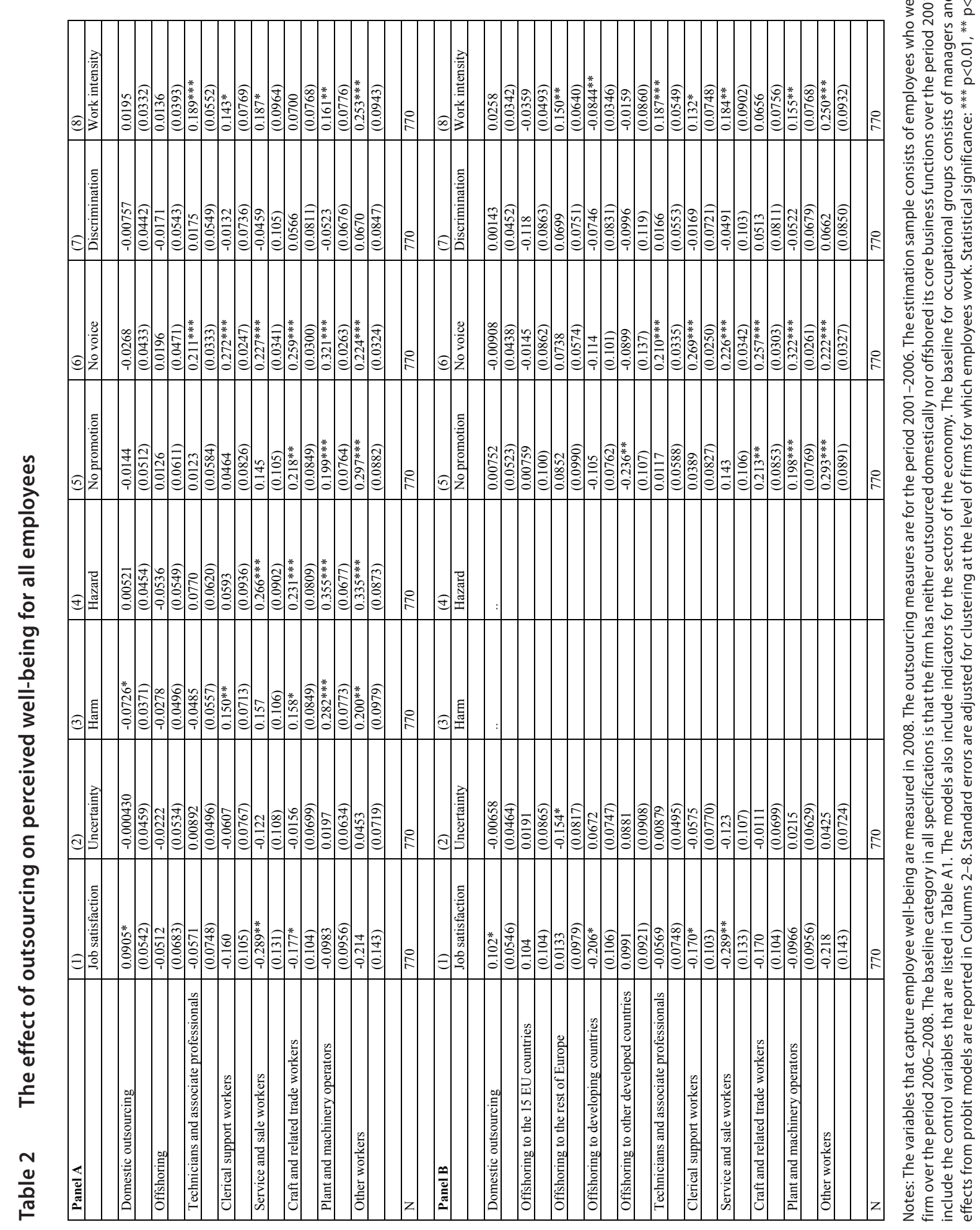


evant to the surviving employees because previous outsourcing may increase the unemployment risk for years to come.

The specifications documented in Panel A of Table 2 assume that the potential effects of outsourcing on employee well-being are uniform, irrespective of the geographical destination of outsourcing. A detailed breakdown of offshoring by geographical destination reveals interesting heterogeneity in the effects (Table 2, Panel B). ${ }^{14}$ Offshoring to developing countries have some negative effect on overall measure of employee well-being (i.e., job satisfaction) (Panel B, Column 1).

Another interesting finding is that offshoring to the US, Canada, and other developed countries significantly raises surviving employees' perceptions of promotion and wage prospects (Table 2, Panel B, Column 5). This observation is reasonable because Finland is a small, open economy with limited opportunities, especially for highly skilled workers. Thus, offshoring, along with other aspects of globalization, creates opportunities to advance one's career because it effectively broadens the market for talent. Offshoring among developed countries is most likely to be reciprocal, and workers in high-wage countries are complements rather than substitutes (Geishecker et al. 2011). The quantitative magnitude of this effect is substantial because offshoring to the US, Canada, and other developed countries decreases employees' perceptions of poor promotion prospects by $24 \%$. This result is consistent with the pattern in Table 1 (Panel B, Column 4), according to which offshoring to other developed countries substantially increases internal task separation, which measures the vertical mobility of employees in firms. Therefore, the vertical fragmentation of production is closely connected to the vertical mobility of employees in firms that offshore. Furthermore, there is evidence for another positive effect of offshoring on employee well-being: the results suggest that offshoring to developing countries decreases perceived work intensity among surviving employees ( $\mathrm{Ta}$ ble 2, Panel B, Column 8). However, offshoring to the rest of Europe increases work intensity.

Table 3 documents a separate set of estimates for knowledge workers because this group of employees is more likely to benefit from outsourcing in terms of well-being than are other worker groups. The results in Panel A reveal that offshoring decreases the prevalence of harm (Column 3). There are also significant effects regarding discrimination (Column 7). However, these effects are contradictory in that domestic outsourcing increases the perception of discrimination among surviving knowledge workers, but offshoring seems to decrease it. The estimates that break down according to the geographical destination of offshoring show that offshoring to the $15 \mathrm{EU}$ countries decreases the perception of discrimination. It is also notable that domestic outsourcing, along with offshoring to the $15 \mathrm{EU}$ countries, improves the level of job satisfaction (Panel B, Column 1). However, negative well-being effects for knowledge workers also exist because offshoring to developing countries significantly increases the perception of uncertainty (Panel B, Column 2). The pattern in which offshoring to other developed countries considerably improves promotion prospects remains intact for knowledge workers (Panel B, Column 5).

Occupational Restructuring and the Well-being of Employees. The concluding section of the main estimation results explores the effect of occupational restructuring among the continu-

\footnotetext{
14 We do not report the results for harm and hazard for these specifications because some cells of the data contain too few observations to obtain reliable estimates.
} 


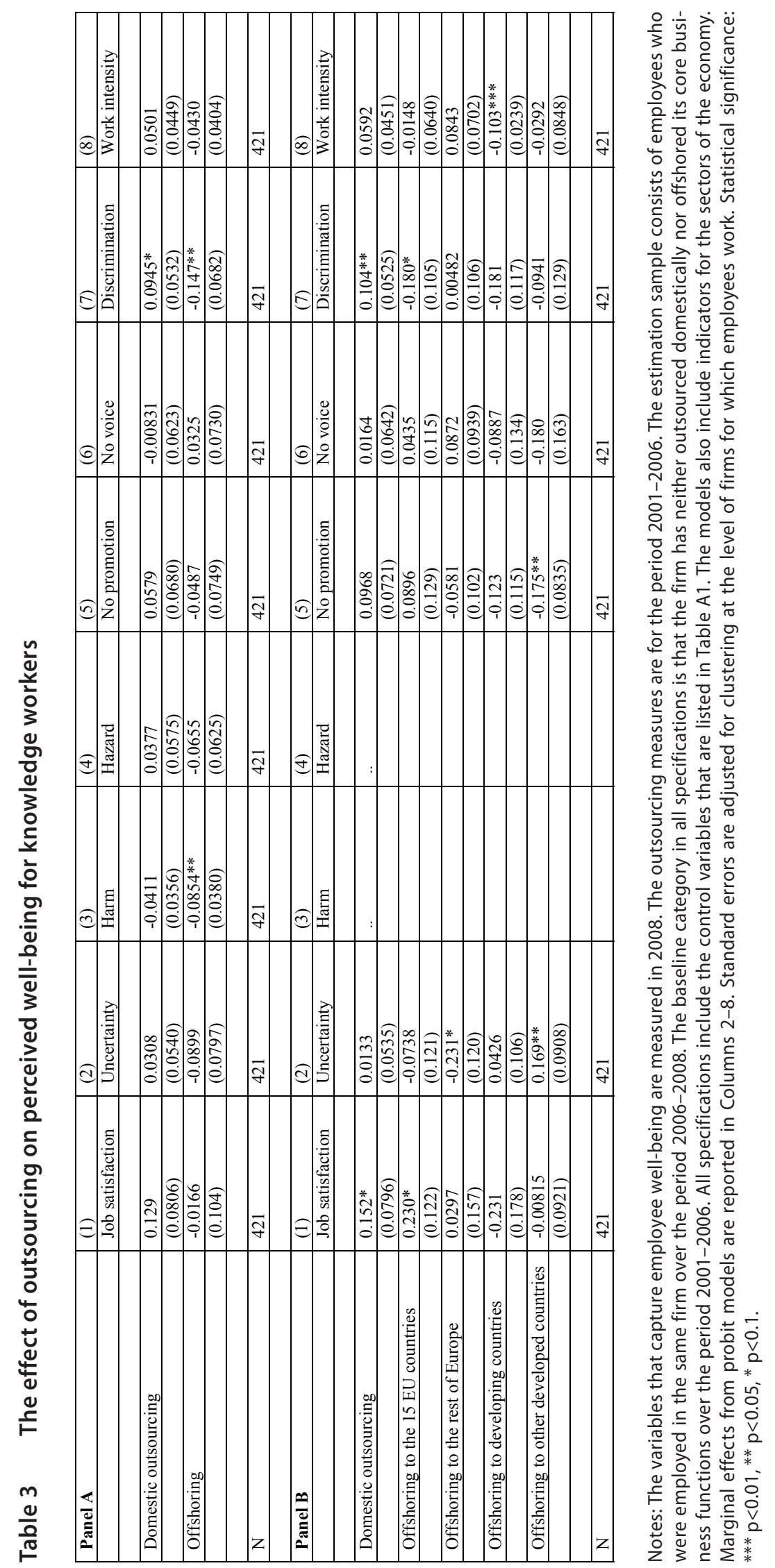


ing firms between 2000 and 2006 on surviving employees' well-being two years later, in 2008 (Table 4). We use exactly the same measures of perceived well-being as the dependent variables used in Tables 2-3. The most important finding of the specifications, based on equation (3), is that there is generally no statistically significant relationship between occupational restructuring and subsequent employee well-being (Table 4). Thus, it seems that occupational restructuring does not have significant additional negative effects on employees beyond its direct adverse effects, documented in Table 1. This general pattern is consistent with the results in Böckerman et al. (2011), who have reported that average uncertainty at the establishment level does not cause significant losses in work satisfaction in the Finnish context.

Occupational restructuring, measured by changes in the shares of interactive and non-routine tasks, significantly reduces the experience of lacking a voice in the workplace, especially among knowledge workers (Table 4, Panel B, Column 6). This result is interesting because Autor et al. (2003) stress the importance of skill content in job tasks. Furthermore, there is evidence that an increase in the share of knowledge workers in a firm significantly improves employees' experience of having a voice in the workplace (Table 4, Panel B, Column 6) and, consistent with that outcome, increases job satisfaction (Table 4, Panel B, Column 1).

Additional Aspects. To shed more light on the effects of offshoring, we estimated a set of additional specifications. We briefly discuss these results without presenting them in tables. As a robustness check, we performed the estimations of Table 1 using unweighted regressions, with and without a size restriction for firms (i.e., the inclusion of firms employing fewer than 100 employees). The baseline results in Table 1 seem to remain largely intact in unweighted regressions and in those without a size restriction. However, there are also some important differences; in these results, offshoring is not negatively associated with task creation and task hiring. Furthermore, offshoring does not have a positive impact on the share of knowledge workers in the firms. Thus, it is important to use employment-weighted regressions to empirically capture the creative side of offshoring. Furthermore, the results in Table 1 (Panel B, Column 1 ), which suggest that offshoring to developing countries leads to task destruction and task separation, do not prevail in unweighted regressions.

One of the strengths of the ISS for outsourcing activities is that it contains information about firms' self-declared motivations for conducting offshoring. There is evidence that the effects on employee well-being differ significantly according to the motivation for offshoring. In particular, an important result in Table 2 (Panel B, Column 5), which reveals that offshoring significantly improves surviving employees' perception of promotion prospects, prevails only when offshoring is motivated by opening new markets for products and services rather than by efforts to reduce labor costs. (Furthermore, there is a significant decrease in the perception of discrimination.) This finding is logical because this type of offshoring constitutes substantial opportunities for career advancement, especially for knowledge workers.

Finally, we find that insourcing (i.e., the opposite of offshoring) generally improves employee well-being. In particular, the results suggest that insourcing significantly decreases the likelihood of perceived harms and hazards in the workplace. This finding is reasonable because the cost structure is higher in Finland than in several other countries that were previously locations for these activities. The types of jobs that are insourced to Finland are high-quality jobs with high wages and amenities that support the perception of good working conditions among the affected employees. There is also some evidence that insourcing supports overall satisfaction at work. 


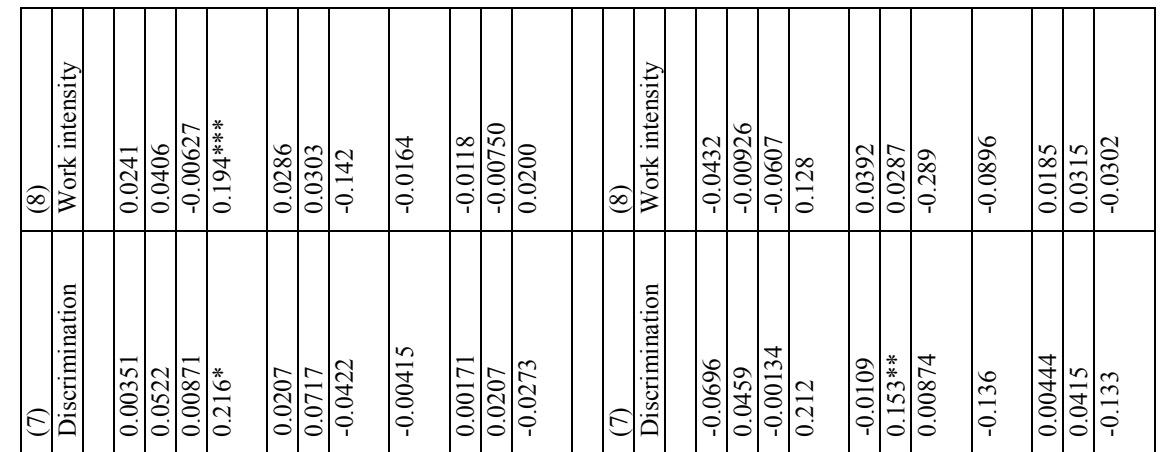

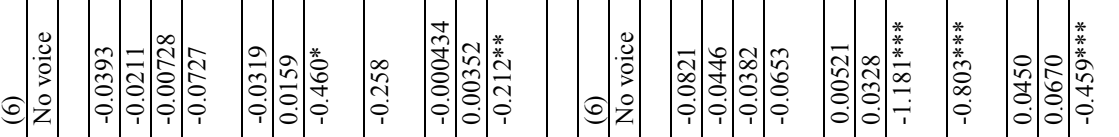<smiles>C1=CC=C1</smiles>

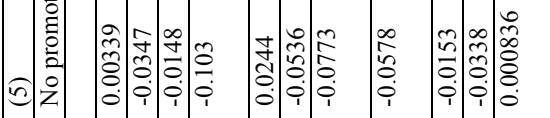

(1)
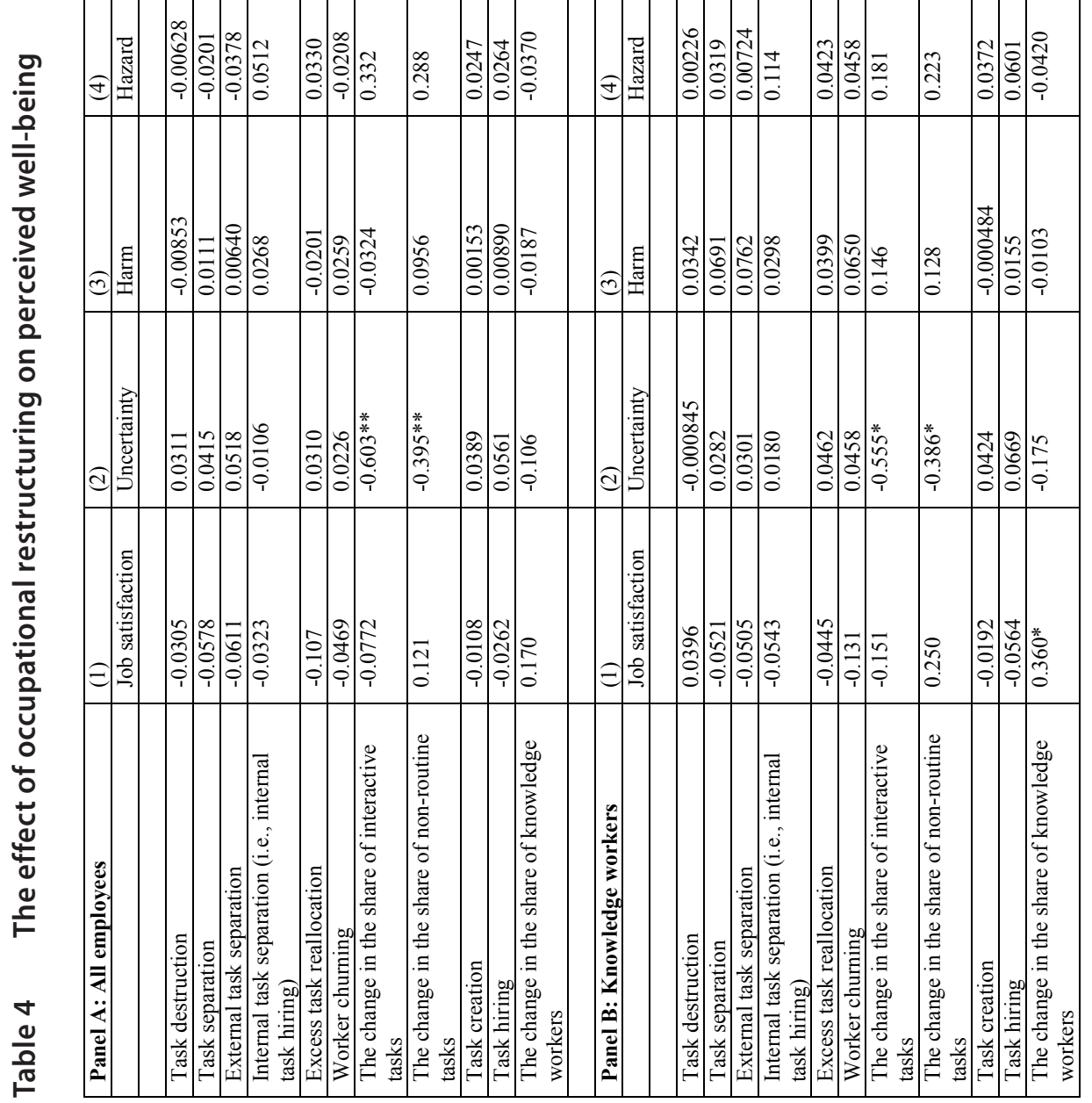

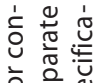

홍

들

要

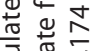

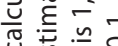

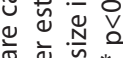

들 능

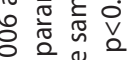

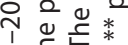

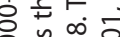

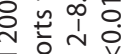

은

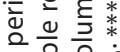

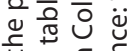

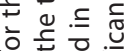

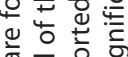

웡 응

(둥

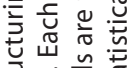

닝

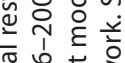

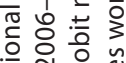

늠 웜

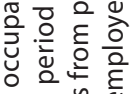
흔

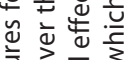

可

政

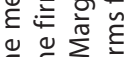

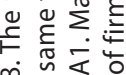

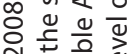

$\leq . \leq$

의

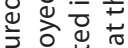

ङ

$\stackrel{\alpha}{\bar{\sigma}}$

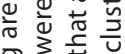

이의

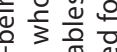

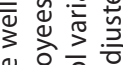

응응

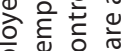

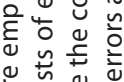

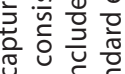

记

둥

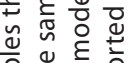

음

गे है

恼

is

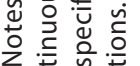




\section{Conclusions}

This paper examines the effects of outsourcing on various measures of employee well-being in the Finnish context. The well-being losses caused by the vertical fragmentation of production potentially constitute an important part of the short-run adjustment costs to employees, and they can explain the persistent resistance to outsourcing. We use particularly rich matched data that combine a firm-level survey of outsourcing with a survey of employees that contains detailed information on several aspects of subjective well-being. Furthermore, we analyze the connection of outsourcing to comprehensive measures of occupational restructuring.

Aside from the direct negative effect of offshoring on employees (attributable to greater job destruction and worker outflow), based on the evidence, the relationship between outsourcing and employee well-being is complex. The main finding of this paper is that the results strongly point to the substantial heterogeneity in the effects of offshoring. For example, we find that the relationship between outsourcing and perceived well-being differs considerably according to the geographical destination of offshoring. There is some evidence that offshoring to developing countries reduces overall satisfaction at work. One explanation for this outcome is that offshoring to low-wage countries substitutes for domestic employment (Harrison and McMillan 2011).

Aside from these negative effects, offshoring also has plausible positive effects on employee well-being that have largely been overlooked in the existing literature. We document that higher occupational status clearly improves well-being at work, and offshoring considerably increases the share of knowledge workers in firms. Importantly, in addition to this direct composition effect, there is also evidence for the existence of positive independent effects. Therefore, even given the prevailing structure of different occupations in the firms, an increase in the share of knowledge workers improves some important aspects of perceived employee wellbeing.

Furthermore, we find that offshoring to other developed countries improves surviving employees' promotion and subsequent wage prospects. These effects are particularly pronounced for knowledge workers and when offshoring has been motivated by opening new markets for products and services. These effects are consistent with the findings by Hickman and Olney (2011), who argue that employees have responded to offshoring by increasing their stock of human capital by acquiring better education in the U.S. context. Better education creates opportunities for career advancement because the market for talented workers is larger (Kauhanen and Napari 2011). The fact that promotion prospects are particularly sensitive to offshoring is also reasonable because harms and hazards are closely related to the fixed stock of capital that constitutes the physical work environment, which does not change rapidly in firms. In contrast, promotion prospects are related to expectations that can change rapidly as a firm changes. Therefore, the bottom line of the findings is that offshoring not only has negative effects on the well-being of surviving employees, but its effects differ substantially by the type of offshoring and by outcomes.

A straightforward generalization of our results at the level of the whole economy involves a potential fallacy of composition. The estimated positive well-being effects on surviving employees do not provide a complete picture of the total impact of offshoring on well-being because 
those who end up unemployed are excluded. Therefore, empirically, a broader and more balanced picture would require analyses of what happens to those individuals who lose their jobs due to offshoring. What is the quality of jobs for which they are hired? The empirical evidence is somewhat reassuring. A large majority of the unemployed will find a new job eventually, and the newly created jobs are usually more productive than the destroyed old jobs. For example, previous Finnish evidence suggests that a significant proportion of aggregate productivity growth can be attributed to the creation of new jobs and the destruction of old jobs, at least in manufacturing (Maliranta et al. 2010). In contrast, focusing on the post-recession years 19921997, Ilmakunnas and Maliranta (2004) show that old and low-productivity plants have high separation rates to unemployment, and new and high-productivity plants have high hiring rates from unemployment. In terms of social policy, the primary challenge is to both strengthen the positive effects of offshoring-triggered restructuring and to facilitate adjustment to the negative impacts, including greater turbulence and polarization in the labor markets. 


\section{Appendix}

\section{Table A1 Definitions of variables}

\begin{tabular}{|c|c|}
\hline Variable & Definition/measurement \\
\hline \multicolumn{2}{|l|}{$\begin{array}{l}\text { The measures of perceived } \\
\text { employee well-being (QWLS) }\end{array}$} \\
\hline Job satisfaction & $\begin{array}{l}\text { Job satisfaction is measured by means of alternatives } 1 \text { (very satisfied), } 2 \\
\text { (quite satisfied), } 3 \text { (rather dissatisfied), and } 4 \text { (very dissatisfied). }\end{array}$ \\
\hline Uncertainty & $\begin{array}{l}\text { Work including at least one insecurity factor (includes transfer to other duties, } \\
\text { threat of temporary dismissal, threat of permanent dismissal, threat of } \\
\text { unemployment, threat of becoming incapable of work, unforeseen changes, } \\
\text { work load increasing beyond tolerance) }=1 \text {, otherwise }=0 \text {. }\end{array}$ \\
\hline Harm & $\begin{array}{l}\text { At least one adverse factor that affects work 'very much' (includes heat, cold, } \\
\text { vibration, draft, noise, smoke, gas and fumes, humidity, dry indoor air, dust, } \\
\text { dirtiness of work environment, poor or glaring lighting, irritating or corrosive } \\
\text { substances, restless work environment, repetitive and monotonous } \\
\text { movements, difficult or uncomfortable working positions, time pressure and } \\
\text { tight time schedules, heavy lifting, lack of space, mildew in buildings) = } 1 \text {, } \\
\text { otherwise }=0 \text {. }\end{array}$ \\
\hline Hazard & $\begin{array}{l}\text { At least one factor experienced as 'a distinct hazard' (includes accident risk, } \\
\text { becoming subject to physical violence, hazards caused by chemical } \\
\text { substances, radiation hazard, major catastrophe hazard, hazard of infectious } \\
\text { diseases, hazard of skin diseases, cancer risk, risk of strain injuries, risk of } \\
\text { succumbing to mental disturbance, risk of grave work exhaustion, risk of } \\
\text { causing serious injury to others, risk of causing serious damage to valuable } \\
\text { equipment or product) }=1 \text {, otherwise }=0 \text {. }\end{array}$ \\
\hline No promotion & Advancement opportunities in current workplace 'poor' $=1$, otherwise $=0$. \\
\hline No voice & $\begin{array}{l}\text { 'Not at all' able to influence at least one factor at work (includes content of } \\
\text { tasks, order in which tasks are completed, pace of work, working methods, } \\
\text { division of tasks between employees, choice of working partners, equipment } \\
\text { purchases) }=1 \text {, otherwise }=0 \text {. }\end{array}$ \\
\hline Discrimination & $\begin{array}{l}\text { Experience of at least one type of unequal treatment or discrimination in } \\
\text { current workplace (includes time of hiring, remuneration, career advancement } \\
\text { opportunities, access to training arranged by employer, receiving information, } \\
\text { attitudes of co-workers or superiors) }=1 \text {, otherwise }=0 \text {. }\end{array}$ \\
\hline Work intensity & $\begin{array}{l}\text { Intensity at work is high enough to cause sickness absence }=1 \text {, otherwise } \\
0 .\end{array}$ \\
\hline \multicolumn{2}{|l|}{$\begin{array}{l}\text { The measures of outsourcing } \\
\text { (ISS) }\end{array}$} \\
\hline Domestic outsourcing & $\begin{array}{l}\text { Firm has domestically outsourced its core business functions (i.e., } \\
\text { production of goods and/or services) over the period 2001-2006 = } 1 \text {, } \\
\text { otherwise } 0 \text {. }\end{array}$ \\
\hline $\begin{array}{l}\text { Offshoring (i.e. international } \\
\text { outsourcing) }\end{array}$ & $\begin{array}{l}\text { Firm has offshored abroad its core business functions over the period } \\
2001-2006=1 \text {, otherwise } 0 .\end{array}$ \\
\hline $\begin{array}{l}\text { Offshoring to the } 15 \mathrm{EU} \\
\text { countries }\end{array}$ & $\begin{array}{l}\text { Firm has offshored its core business functions to the } 15 \mathrm{EU} \text { countries over } \\
\text { the period } 2001-2006=1 \text {, otherwise } 0 \text {. The EU } 15 \text { countries are Belgium, } \\
\text { Denmark, Germany, Greece, Spain, France, Ireland, Italy, Luxembourg, } \\
\text { Netherlands, Austria, Portugal, Sweden, and the United Kingdom. Finland } \\
\text { is excluded from the list of the EU } 15 \text { countries. }\end{array}$ \\
\hline Offshoring to the rest of Europe & $\begin{array}{l}\text { Firm has offshored its core business functions to the rest of Europe over } \\
\text { the period } 2001-2006=1 \text {, otherwise } 0 \text {. The rest of Europe includes } 12 \mathrm{EU} \\
\text { countries (i.e., Czech Republic, Estonia, Cyprus, Latvia, Lithuania, } \\
\text { Hungary, Malta, Poland, Slovenia, Slovak Republic, Bulgaria, and } \\
\text { Romania) and Switzerland, Norway, Turkey, Russia, Belo Russia, } \\
\text { Ukraine, and the Balkan states. }\end{array}$ \\
\hline $\begin{array}{l}\text { Offshoring to developing } \\
\text { countries }\end{array}$ & $\begin{array}{l}\text { Firm has offshored its core business functions to developing countries } \\
\text { over the period } 2001-2006=1 \text {, otherwise } 0 \text {. The developing countries } \\
\text { include China, India, South and Central America (including Mexico), and } \\
\text { Africa. }\end{array}$ \\
\hline
\end{tabular}




\begin{tabular}{|c|c|}
\hline $\begin{array}{l}\text { Offshoring to other developed } \\
\text { countries }\end{array}$ & $\begin{array}{l}\text { Firm has offshored its core business functions to other developed } \\
\text { countries over the period 2001-2006 = 1, otherwise } 0 \text {. The other } \\
\text { developed countries include the US, Canada, Japan, Korea, the countries } \\
\text { of the Near East and Far East, and Oceania. }\end{array}$ \\
\hline \multicolumn{2}{|l|}{ Control variables } \\
\hline \multicolumn{2}{|l|}{ Human capital (QWLS) } \\
\hline Female & $1=$ female, $0=$ male \\
\hline Age $<=34$ & Age $<=34=1$, otherwise $=0$. \\
\hline Age 35-44 & Age 35-44 =1, otherwise $=0$ (reference) \\
\hline Age 45-54 & Age $45-54=1$, otherwise $=0$ \\
\hline Age 55-64 & Age 55-64 $=1$, otherwise $=0$ \\
\hline Married & Married $=1$, otherwise $=0$ \\
\hline Basic education only & $\begin{array}{l}\text { Less than second stage of secondary level education (International } \\
\text { Standard Classification of Education (ISCED) } 0-2 \text { ) }=1 \text {, otherwise }=0 \\
\text { (reference). }\end{array}$ \\
\hline Middle education & Second stage of secondary level education $($ ISCED 3$)=1$, otherwise $=0$ \\
\hline Higher education & Third-level education $($ ISCED 5-7) $=1$, otherwise $=0$ \\
\hline Union member & Member of trade union $=1$, otherwise $=0$. \\
\hline \multicolumn{2}{|l|}{ Work history (FLEED) } \\
\hline Past earnings & $\begin{array}{l}\text { A logarithm of past average earnings over the period 1990-2007, deflated } \\
\text { to the year } 2000 \text { by using the consumer price index. }\end{array}$ \\
\hline Past employment & The total number of employment months over the period 1990-2007. \\
\hline Past unemployment & The total number of unemployment months over the period 1990-2007. \\
\hline Self-assessed health (QWLS) & $\begin{array}{l}\text { Self-assessment of working capacity. The variable is scaled from } 0 \text { (total } \\
\text { inability to work) to } 10 \text { (top condition). }\end{array}$ \\
\hline \multicolumn{2}{|l|}{$\begin{array}{l}\text { Employer characteristics } \\
\text { (QWLS) }\end{array}$} \\
\hline Plant size $<100$ & Size of plant under 100 employees $=1$, otherwise $=0$ (reference) \\
\hline Plant size 100-249 & Size of plant $100-249$ employees $=1$, otherwise $=0$ \\
\hline Plant size 250-999 & Size of plant 250-999 employees $=1$, otherwise $=0$ \\
\hline Plant size $>1000$ & Size of plant over 1000 employees $=1$, otherwise $=0$ \\
\hline
\end{tabular}

Note: The measures of occupational restructuring are defined in the text. 


\section{Table A2 Selected descriptive statistics for the linked data sets}

\section{Outsourcing variables (ISS) \\ Domestic outsourcing \\ Offshoring \\ Offshoring to the $15 \mathrm{EU}$ countries \\ Offshoring to the rest of Europe \\ Offshoring to developing countries \\ Offshoring to other developed countries \\ Occupational restructuring variables (FLEED)}

Task destruction

Task separation

External task separation

Internal task separation (i.e., internal task hiring)

Excess task reallocation

Task churning

The change in the share of interactive tasks

The change in the share of non-routine tasks

Task creation

Task hiring

The change in the share of knowledge workers

The share of knowledge workers in 2006

Well-being variables (QWLS)

Job satisfaction
Uncertainty
Harm
Hazard
No promotion
No voice
Discrimination
Work intensity

Occupational share variables (FLEED)

Technicians and associate professionals

Clerical support workers

Service and sale workers

Craft and related trade workers

Plant and machinery operators

Other workers

\begin{tabular}{|c|c|c|c|c|c|c|}
\hline \multicolumn{3}{|c|}{$\begin{array}{l}\text { Firm-level data on outsourcing } \\
\text { and restructuring }\end{array}$} & \multicolumn{2}{|c|}{$\begin{array}{l}\text { Individual-level data on } \\
\text { outsourcing and well-being }\end{array}$} & \multicolumn{2}{|c|}{$\begin{array}{l}\text { Individual-level data on } \\
\text { restructuring } \\
\text { and well-being }\end{array}$} \\
\hline $\mathrm{N}$ & Weighted N & Mean & $\mathrm{N}$ & Mean & $\mathrm{N}$ & Mean \\
\hline 1096 & 353698 & 0.222 & 770 & 0.209 & & \\
\hline 1096 & 353698 & 0.147 & 770 & 0.138 & & \\
\hline 1096 & 353698 & 0.222 & 770 & 0.209 & & \\
\hline 1096 & 353698 & 0.052 & 770 & 0.044 & & \\
\hline 1096 & 353698 & 0.083 & 770 & 0.081 & & \\
\hline 1096 & 353698 & 0.063 & 770 & 0.057 & & \\
\hline 1096 & 353698 & 0.204 & & & 1174 & 0.189 \\
\hline 1096 & 353698 & 0.562 & & & 1174 & 0.506 \\
\hline 1096 & 353698 & 0.394 & & & 1174 & 0.354 \\
\hline 1096 & 353698 & 0.167 & & & 1174 & 0.152 \\
\hline 1096 & 353698 & 0.170 & & & 1174 & 0.212 \\
\hline 1096 & 353698 & 0.714 & & & 1174 & 0.635 \\
\hline 1096 & 353698 & 0.007 & & & 1171 & 0.008 \\
\hline 1096 & 353698 & 0.014 & & & 1171 & 0.012 \\
\hline 1096 & 353698 & 0.387 & & & 1174 & 0.472 \\
\hline 1096 & 353698 & 0.744 & & & 1174 & 0.789 \\
\hline 1096 & 353698 & 0.022 & & & 1174 & 0.009 \\
\hline 1096 & 353698 & 0.476 & & & 1174 & 0.461 \\
\hline & & & 770 & 4.048 & 1174 & 4.072 \\
\hline & & & 770 & 0.723 & 1174 & 0.664 \\
\hline & & & 770 & 0.281 & 1174 & 0.245 \\
\hline & & & 770 & 0.397 & 1174 & 0.365 \\
\hline & & & 770 & 0.418 & 1174 & 0.486 \\
\hline & & & 770 & 0.705 & 1174 & 0.677 \\
\hline & & & 770 & 0.377 & 1174 & 0.343 \\
\hline & & & 770 & 0.169 & 1165 & 0.121 \\
\hline & & & 770 & 0.216 & 1174 & 0.195 \\
\hline & & & 770 & 0.110 & 1174 & 0.092 \\
\hline & & & 770 & 0.078 & 1174 & 0.102 \\
\hline & & & 770 & 0.129 & 1174 & 0.164 \\
\hline & & & 770 & 0.169 & 1174 & 0.172 \\
\hline & & & 770 & 0.078 & 1174 & 0.067 \\
\hline
\end{tabular}




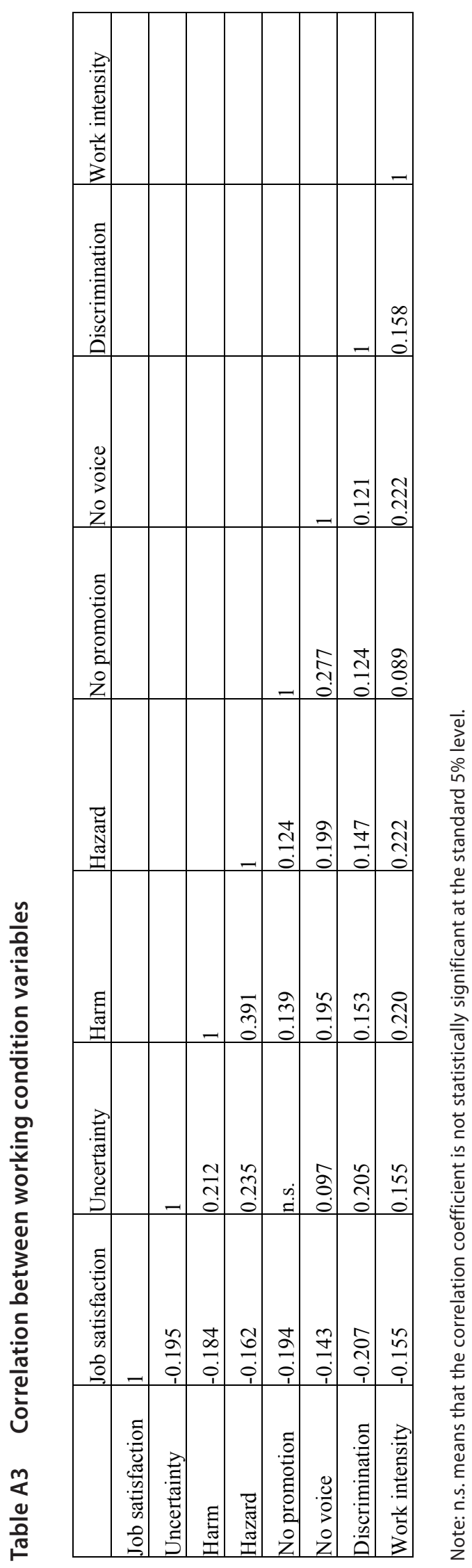




\section{References}

Abowd, John M., Francis Kramarz, and David N. Margolis. 1999. “High Wage Workers and High Wage Firms." Econometrica 67(March): 251-333.

Ali-Yrkkö, Jyrki. 2007. “Tuotannon ja T\&K-toiminnan ulkoistaminen - motiivit ja onnistuminen.” Discussion Paper No. 1071. Helsinki: The Research Institute of the Finnish Economy.

Ali-Yrkkö, Jyrki, Petri Rouvinen, Timo Seppälä, and Pekka Ylä-Anttila. 2011. “Who Captures Value in Global Supply Chains? Case Nokia N95 Smartphone." Journal of Industry, Competition and Trade 11(3): 263-278.

Askenazy, Philippe, and Eva Moreno Galbis. 2007. "The Impact of Technological and Organizational Changes on Labor Flows. Evidence on French Establishments." Labour: Review of Labour Economics and Industrial Relations 21(2): 265-301.

Autor, David H., Frank Levy, and Richard J. Murmane. 2003. "The Skill Content of Recent Technological Change: An Empirical Exploration." Quarterly Journal of Economics 118(November): 1279-1333.

Bagger, Jesper, Bent Jesper Christensen, and Dale T. Mortensen. 2010. “Wage and Productivity Dispersion: Labour Quality or Rent Sharing?" Royal Holloway, University of London.

Baldwin, Richard. 2006. Globalisation: The Great Unbundling(s). Helsinki: Economic Council of Finland, Prime Minister's Office.

Bauer, Thomas K., and Stefan Bender. 2004. "Technological Change, Organizational Change, and Job Turnover." Labour Economics 11(June): 265-291.

Becker, Sascha O., Karolina Ekholm, and Marc-Andreas Muendler. 2009. "Offshoring and the Onshore Composition of Occupations, Tasks and Skills." Discussion Paper No. 7391. London: Centre for Economic Policy Research.

Blinder, Alan S. 2006. "Offshoring: The Next Industrial Revolution." Foreign Affairs 85(March/April): 113128.

Burgess, Simon, Julia Lane, and David Stevens. 2000. "Job Flows, Worker Flows, and Churning." Journal of Labor Economics 18(July): 473-502.

Böckerman, Petri, and Pekka Ilmakunnas. 2008. "Interaction of Working Conditions, Job Satisfaction, and Sickness Absences: Evidence from a Representative Sample of Employees." Social Science and Medicine 67(August): 520-528.

Böckerman, Petri, Pekka Ilmakunnas, and Edvard Johansson. 2011. "Job Security and Employee Wellbeing: Evidence from Matched Survey and Register Data." Labour Economics 18(August): 547-554.

Clark, Andrew E. 1996. "Job Satisfaction in Britain." British Journal of Industrial Relations 34(June): 189-217.

Crinò, Rosario. 2009. "Offshoring, Multinationals and Labour Market: A Review of the Empirical Literature." Journal of Economic Surveys 23(April): 197-249.

Davis, Steven J., and John Haltiwanger. 1999. "Gross Job Flows." In Handbook of Labor Economics, Volume 3B, edited by Orley Ashenfelter and David Card, pp. 2711-2805. Amsterdam: Elsevier. 
Outsourcing, Occupational Restructuring, and Employee Well-being:

Is There a Silver Lining?

Eriksson, Tor. 2010. “Labour Market Outcomes of Internationalization - What Have We Learnt from Analyses of Microdata on Firms and Their Employees?" In Wage Structures, Employment Adjustment and Globalization, edited by David Marsden and Francois Rycx, pp. 221-243. New York: Palgrave Macmillan.

Geishecker, Ingo. 2008. "The Impact of International Outsourcing on Individual Employment Security: A Micro-level Analysis." Labour Economics 15(June): 291-314.

Geishecker, Ingo, Maximilian Riedl, and Paul Frijters. 2011. “Offshoring and Job Loss Fears: An Econometric Analysis of Individual Perceptions." Georg-August-Universität Göttingen.

Griliches, Zvi, and Jerry A. Hausman. 1986. "Errors in Variables in Panel Data." Journal of Econometrics 31(February): 93-118.

Harrison, Ann, and Margaret McMillan. 2011. "Offshoring Jobs? Multinationals and U.S. Manufacturing Employment." Review of Economics and Statistics 93(August): 857-875.

Hickman, Daniel C., and William W. Olney. 2011. "Globalization and Investment in Human Capital." Industrial and Labor Relations Review 64(July): 654-672.

Hopp, Wallace J., Seyed M. R. Iravani, and Fang Liu. 2009. “Managing White-collar Work: An Operationsoriented Survey." Production and Operations Management 18(1): 1-32.

Ilmakunnas, Pekka, and Mika Maliranta. 2004. "Hiring from Unemployment and Separation to Unemployment." Applied Economics Letters 11(2): 91-95.

Ilmakunnas, Pekka, and Mika Maliranta. 2005. "Worker Inflow, Outflow, and Churning." Applied Economics 37(10): 1115-1133.

Ilmakunnas, Pekka, and Mika Maliranta. 2011. "Suomen työpaikka- ja työntekijävirtojen käänteitä: Toimialojen elinkaaret ja finanssikriisit." Työpoliittinen aikakauskirja 54(2): 6-23.

Kauhanen, Antti, and Sami Napari. 2011. “Career and Wage Dynamics: Evidence from Linked Employeremployee Data." Research in Labor Economics, Forthcoming.

Lechner, Michael, and Conny Wunsch. 2011. "Sensitivity of Matching-based Program Evaluations to the Availability of Control Variables." Discussion Paper No. 5553. Bonn: Institute for the Study of Labor.

Lehto, Anna-Maija, and Hanna Sutela. 2009. Three Decades of Working Conditions. Findings of Finnish Quality of Work Life Surveys 1977-2008. Statistics Finland: Helsinki.

Linden, Greg, Kenneth L. Kraemer, and Jason Dedrick. 2007. “Who Captures Value in a Global Innovation System? The case of Apple's iPod." University of California, Irvine.

Lurweg, Maren. 2010. “Perceived Job Insecurity, Unemployment Risk and International Trade - A Microlevel Analysis of Employees in German Service Industries." DIW Berlin: SOEP Papers on Multidisciplinary Panel Data Research No. 300.

Maertz Jr, Carl P., Jack W. Wiley, Cynthia LeRouge, and Michael A. Campion. 2009. “Downsizing Effects on Survivors: Layoffs, Offshoring, and Outsourcing." Industrial Relations 49(April): 275-285.

Maliranta, Mika. 2009. “Työpaikka- ja työntekijävirrat ja tehtävärakenteiden dynamiikka Suomen yrityssektorilla." Discussion Paper No. 1177. Helsinki: The Research Institute of the Finnish Economy. 
Maliranta, Mika. 2011. "Globalization, Occupational Restructuring and Firm Productivity." Manuscript. Helsinki: The Research Institute of the Finnish Economy.

Maliranta, Mika, Petri Rouvinen, and Pekka Ylä-Anttila. 2010. “Finland's Path to Global Productivity Frontiers Through Creative Destruction." International Productivity Monitor 20(10): 68-84.

Malone, Thomas W., Robert J. Laubacher, and Tammy Johns. 2011. "The Age of Hyperspecialization." Harvard Business Review July-August, 56-65.

Munch, Jakob R. 2010. “Whose Job Goes Abroad? International Outsourcing and Individual Job Separations." Scandinavian Journal of Economics 112(2): 339-360.

Nilsson Hakkala, Katariina, Fredrik Heyman, and Fredrik Sjöholm. 2009. “Multinational Firms and Job Tasks." Working Paper No. 8/2009. Helsinki: Government Institute for Economic Research.

Østhus, Ståle, and Arne Mastekaasa. 2010. "The Impact of Downsizing on Remaining Workers' Sickness Absence." Social Science and Medicine 71(October): 1455-1462.

Sacks, Daniel W., Betsey Stevenson, and Justin Wolfers. 2010. "Subjective Well-being, Income, Economic Development and Growth." Discussion Paper No. 8048. London: Centre for Economic Policy Research.

Scheve, Kenneth, and Matthew J. Slaughter. 2004. "Economic Insecurity and the Globalization of Production." American Journal of Political Science 48(October): 662-674.

Statistics Denmark, Statistics Finland, Statistics Netherlands, Statistics Norway, and Statistics Sweden. 2008. International Sourcing. Moving Business Functions Abroad. Copenhagen: Statistics Denmark. Available at http://www.dst.dk/publikation.aspx?cid=13110

Stevenson, Betsey, and Justin Wolfers. 2008. "Economic Growth and Subjective Well-being: Reassessing the Easterlin Paradox." Brookings Papers on Economic Activity 1:1-87.

Wagner, Joachim. 2011. "Productivity and International Firm Activities: What Do We Know?" IZA Policy Paper No. 23. Bonn: Institute for the Study of Labor. 



\section{Aikaisemmin ilmestynyt ETLAn Keskusteluaiheita-sarjassa Previously published in the ETLA Discussion Papers Series}

No 1256 Jari Hyvärinen, Innovaatiotoiminta: Näkemyksiä hyvinvointialaan ja työelämän kehittämiseen. 31.8.2011. $28 \mathrm{~s}$.

No 1257 Terttu Luukkonen - Matthias Deschryvere - Fabio Bertoni - Tuomo Nikulainen, Importance of the Non-financial Value Added of Government and Independent Venture Capitalists. 2.9.2011. 28 p.

No 1258 Ari Hyytinen - Mika Pajarinen - Pekka Ylä-Anttila, Finpron vaikuttavuus - Finpron palveluiden käytön vaikutukset yritysten kansainvälistymiseen ja menestymiseen. 15.9.2011. $32 \mathrm{~s}$.

No 1259 Kari E.O. Alho, How to Restore Sustainability of the Euro? 19.9.2011. 27 p.

No 1260 Heli Koski, Does Marginal Cost Pricing of Public Sector Information Spur Firm Growth? 28.9.2011. 15 p.

No 1261 Valeriy Naumov - Olli Martikainen, Method for Throughput Maximization of Multiclass Networks with Flexible Servers. 13.12.2011. 19 p.

No 1262 Valeriy Naumov - Olli Martikainen, Optimal Resource Allocation in Multiclass Networks. 14.12.2011. 17 p.

No 1263 Jari Hyvärinen, Innovaatiotoiminta: Suomi globaalitaloudessa. 30.12.2011. 49 s.

No 1264 Jari Hyvärinen, Productivity: An International Comparison. 30.12.2011. 20 p.

No 1265 Jukka Lassila - Tarmo Valkonen - Juha M. Alho, Fiscal Sustainability and Policy Rules under Changing Demographic Forecasts. 21.12.2011. 32 p.

No 1266 Reijo Mankinen - Olavi Rantala, Ulkomaanliikenteen palveluiden arvonlisäverotuksen käyttöönoton vaikutukset laiva- ja lentoliikenteeseen. 11.1.2012. $29 \mathrm{~s}$.

No 1267 Ville Kaitila - Pekka Ylä-Anttila, Investoinnit Suomessa. Kehitys ja kansainvälinen vertailu. 30.1.2012. 34 s.

No 1268 Valeriy Naumov - Olli Martikainen, Queueing Systems with Fractional Number of Servers. 21.3.2012. 11 p.

No 1269 Kari E.O. Alho - Nuutti Nikula, Asevelvollisuus ja työmarkkinat. Varusmiespalveluksen vaikutus koulutukseen, työllisyyteen ja palkkaan. 29.3.2012. $25 \mathrm{~s}$.

No 1270 Hannu Hernesniemi, Merenkulun toimintaedellytykset, kilpailukyky ja julkisen talouden sopeuttamistoimet. Taustaselvitys valtiovarainministeriölle. 18.4.2012. $53 \mathrm{~s}$.

Elinkeinoelämän Tutkimuslaitoksen julkaisemat "Keskusteluaiheita" ovat raportteja alustavista tutkimustuloksista ja väliraportteja tekeillä olevista tutkimuksista. Tässä sarjassa julkaistuja monisteita on mahdollista ostaa Taloustieto Oy:stä kopiointi- ja toimituskuluja vastaavaan hintaan.

Papers in this series are reports on preliminary research results and on studies in progress. They are sold by Taloustieto Oy for a nominal fee covering copying and postage costs.

Julkaisut ovat ladattavissa pdf-muodossa osoitteessa: www.etla.fi/julkaisuhaku.php

Publications in pdf can be downloaded at www.etla.fi/eng/julkaisuhaku.php

ETLA

Elinkeinoelämän Tutkimuslaitos

The Research Institute of the Finnish Economy

Lönnrotinkatu 4 B

00120 Helsinki
Puh. 09-609 900

Fax 09-601 753

www.etla.fi

etunimi.sukunimi@etla.fi

ISSN 0781-6847 